\title{
max \\ Harnessing the Antibacterial Properties of Fluoridated Chitosan Polymers against Oral Biofilms
}

\author{
Dien Puji Rahayu $\left.{ }^{1,2}{ }^{(}\right)$, Roger Draheim ${ }^{1}\left(\mathbb{D}\right.$, Aikaterini Lalatsa ${ }^{1, *(\mathbb{C})}$ and Marta Roldo ${ }^{1, *(\mathbb{C})}$ \\ 1 School of Pharmacy and Biomedical Sciences, University of Portsmouth, St Michael's Building, \\ White Swan Road, Portsmouth PO1 2DT, UK; dien.rahayu@port.ac.uk (D.P.R.); \\ roger.draheim@port.ac.uk (R.D.) \\ 2 National Research and Innovation Agency of Indonesia (BRIN), Lebak Bulus Raya No. 49, \\ Jakarta 12440, Indonesia \\ * Correspondence: katerina.lalatsa@port.ac.uk (A.L.); marta.roldo@port.ac.uk (M.R.)
}

Citation: Rahayu, D.P.; Draheim, R.; Lalatsa, A.; Roldo, M. Harnessing the Antibacterial Properties of

Fluoridated Chitosan Polymers against Oral Biofilms. Pharmaceutics 2022, 14, 488. https://doi.org/ $10.3390 /$ pharmaceutics 14030488

Academic Editor: Beom-Jin Lee

Received: 27 January 2022

Accepted: 19 February 2022

Published: 23 February 2022

Publisher's Note: MDPI stays neutral with regard to jurisdictional claims in published maps and institutional affiliations.

Copyright: (C) 2022 by the authors. Licensee MDPI, Basel, Switzerland. This article is an open access article distributed under the terms and conditions of the Creative Commons Attribution (CC BY) license (https:// creativecommons.org/licenses/by/ $4.0 /)$.

\begin{abstract}
Dental caries are a worldwide endemic chronic disease affecting people of all ages. Due to the limitations of daily used oral hygiene products, there is an unmet need for new, effective, safe, and economic oral products. We have recently demonstrated that $N$-(2(2,6-diaminohexanamide)chitosan (CS3H Lys) has enhanced antibacterial properties against Streptococcus mutans, the main cariogenic bacterium, and here we investigated the effect of fluoridation of this polymer (CS3H Lys F) on its antibacterial properties and the ability to protect teeth from acid demineralization. We further formulated this polymer into mouthwash preparations and studied their cytocompatibility and physicochemical stability over 6 months. CS3H Lys F was 1.6-fold more effective than the highest tested oral NaF dose in preventing acid demineralization. CS3H Lys $\mathrm{F}$ has a 3- to 5-fold lower minimum inhibitory concentration value against $S$. mutants than the values reported for chitosan polymers and showed negligible cell toxicity. The mouthwashes were stable at both 25 and $40{ }^{\circ} \mathrm{C}$. Further work is under way towards other CS3H Lys F oral hygiene products such as a toothpaste.
\end{abstract}

Keywords: chitosan; fluoride; antimicrobial properties; demineralization protection; dental caries

\section{Introduction}

Dental caries are a worldwide endemic chronic infection affecting people of all ages [1,2]. Almost half of the world's population is affected by dental caries in permanent teeth [1], with particular high prevalence in young people in developing countries $(79 \%$ in Thailand and $75 \%$ in Malaysia) [3,4]. Dental caries are caused by communities of microorganisms that present on the tooth surface entrapped within the extracellular polymeric substance (EPS) forming the dental biofilm or dental plaque $[5,6]$. The most prevalent cariogenic bacteria are Streptococcus mutans and Streptococcus sobrinus [7,8]. Enamel, the protective external layer of teeth composed of hydroxyapatite, is destroyed when the $\mathrm{pH}$ drops below a critical level $(\mathrm{pH}<5.5)$ due to the ingestion of acidic food and drinks or the production of acid by bacteria [9]. Dental caries are preventable by (a) reducing sugar in the diet, as when metabolized by bacteria, sugar generates acid, and (b) good oral hygiene habits such as brushing teeth twice daily, combined with flossing and rinsing with a mouthwash [10]. There are several antibacterial agents such as triclosan [11,12], essential oils [13,14], cetyl pyridinium chloride [15], zinc sulphate [16], chlorhexidine (CHX) [15-17], or a combination of them that have been shown to control dental biofilm formation and are formulated into toothpastes and mouthwashes for ease of use and topical application [11-16,18-21]. Among these, $\mathrm{CHX}$ remains the gold standard for reducing plaque and gingival inflammation [22,23]. However, CHX causes tooth staining, alters taste perception and promotes calculus or tartar [17,24-27]. Thus, there is need for new, sustainable, effective, safe, and economic substances that can be formulated into daily treatment products and particularly mouth- 
washes that are easier to use and able to reach the narrow and small spaces in the mouth that brushing cannot.

Fluoride containing products and oral solutions remain a widely used cost-effective strategy to prevent dental caries. Fluoride ions are commonly added to oral hygiene products in the form of sodium fluoride, as they are known to disturb the growth and metabolism of cariogenic bacteria by inhibiting enolase, an enzyme involved in glycolysis, thus decreasing acid production and reducing the EPS formation in bacterial biofilms [28-31]. Additionally, fluoride ions promote remineralization of weakened tooth enamel [32,33].

Chitosan, a polysaccharide of a natural origin and a waste product of the fish industry, has been shown to possess an antibacterial activity [34-36], a property that justifies its inclusion in oral hygiene products. Commercially available formulations that contain chitosan as an active ingredient are available and include a chitosan-based, non-fluoride toothpaste (Chitodent $^{\circledR}$, B\&F Elektro GmbH, Filsum, Germany), a chitosan (0.5\%) toothpaste with 1400 ppm fluoride ions $\left(\mathrm{F}^{-}\right)$and 3500 ppm tin ions $\left(\mathrm{Sn}^{+2}\right)\left(\right.$ Elmex $^{\circledR}, \mathrm{GABA}$ International AG, Münchenstein, Switzerland), a chitosan argininamide mouthwash (Synedent ${ }^{\circledR}$, Prisyna, Claremont, CA, USA), and a chitosan argininamide and sodium fluoride $(0.05 \% w / v$ equivalent to $0.02 \% w / v \mathrm{~F}^{-}$) (Synedent FLX, Prisyna, Claremont, CA, USA). All products highlight the natural origin and low environmental impact of chitosan, supporting the wider move of many consumer health product multinational companies towards the use of naturally derived excipients and actives.

We have recently shown that $N$-(2(2,6-diaminohexanamide)-chitosan (CS3H Lys) has enhanced antibacterial properties against $S$. aureus and is able to completely inhibit its growth at concentrations as low as $200 \mu \mathrm{g} \mathrm{mL}^{-1}$ [37]. In this study, we demonstrate, for the first time, the effect of fluoridation of this polymer on its antibacterial properties and its ability to protect teeth from acid demineralization. We have also formulated a cytocompatible and stable (for 6 months) mouthwash readily commercialisable as an oral product.

\section{Materials and Methods}

\subsection{Materials}

Chlorhexidine gluconate $(0.2 \%)$ Minosep ${ }^{\circledR}$ mouthwash (Minorock Mandiri Ltd., Depok, Indonesia) and Listerine ${ }^{\circledR}$ total care (Johnson and Johnson, Maidenhead, UK) were used as the control mouthwashes. 3-(4,5-dimethylthiazol-2yl)-2,5-diphenyltetrazolium bromide (MTT), trypan blue stain, penicillin/streptomycin were purchased from Fisher Scientific (Longborough, UK). All other chemicals used in this study were of analytical grade and were purchased from Sigma Aldrich Inc. (Gillingham, Dorset, UK), unless otherwise stated. CS3H was synthesized by acid degradation [38] of commercially available low-viscosity chitosan from shrimp shell (CAS 9012-96-4, Lot \#BCBQ 3414V, MW: 165.3 KDa, acetylation $15.37 \pm 0.47 \%$ calculated by NMR [37], Sigma-Aldrich Inc. Gillingham, Dorset, UK) and had the following properties: molecular weight $4.709 \times 10^{4} \mathrm{~g} / \mathrm{mL}$, Mn $4.156 \times 10^{4}, \mathrm{Mw} / \mathrm{Mn} 1.133$, acetylation $14.20 \pm 0.17 \%$, and pKa $6.68 \pm 0.06$. N(2(2,6-diaminohexanamide)-chitosan (CS3H Lys) was synthesized from CS3H, as previously described (SI Section S1) [37]. The polymer obtained had a molecular weight of $3.345 \times 10^{4} \mathrm{~g} / \mathrm{mol}\left(\mathrm{Mn} 1.893 \times 10^{4}\right.$ and $\left.\mathrm{Mw} / \mathrm{Mn} 1.768\right)$, acetylation $17.56 \pm 5.23 \%$, and $\mathrm{pKa}$ of $6.56 \pm 0.06$ [37].

\subsection{Fluoridation of Chitosan Polymers and Fluoride Quantification}

Chitosan fluoride (CS3H F) was obtained by the dialysis of chitosan $(1 \mathrm{~g})$ against $1 \mathrm{~L}$ of sodium fluoride solution containing 362.5, 725, and $1450 \mathrm{mg} \mathrm{NaF}$ to obtain $\mathrm{CS}_{\mathrm{H}} \mathrm{H} \mathrm{F}_{\text {low' }}$, $\mathrm{CS} 3 \mathrm{H} \mathrm{F}_{\text {medium, }}$ and $\mathrm{CS} 3 \mathrm{H} \mathrm{F}_{\text {high, }}$, respectively. Dialysis was carried out at room temperature with six changes over $24 \mathrm{~h}$ (MWCO: 12-14 KDa, Medicell Membranes Ltd., London, UK). Similarly, N-(2(2,6-diaminohexanamide)-chitosan fluoride (CS3H Lys F) was obtained by dialysis against $1 \mathrm{~L}$ of sodium fluoride $(725 \mathrm{mg})$ solution immediately after $\mathrm{CS} 3 \mathrm{H}$ 
Lys synthesis (1.54 g scale) [37] without the need for lyophilizing the product first. All dialysates were lyophilized and white polymer products were packaged in sealed polypropylene containers.

Fluoride ion loading was determined using a fluoride ion-selective electrode (ISE) (Orion Star A214, Thermo Scientific, Indonesia) fitted with a fluoride electrode (Thermo Scientific, UK). Distilled water was used for the preparation of samples and standard solutions. A total ionic strength adjustment buffer (TISAB) II with cyclohexylenedinitrilotetraacetate (CDTA) (Thermo Fisher Scientific, Warrington, UK) was used in the potentiometric measurements. Measurements were conducted as per the manufacturer's instructions (Section S1).

\subsection{Fourier-Transform Infrared Spectroscopy (FTIR)}

FTIR spectra of chitosan derivatives were obtained using a Varian FTIR spectrophotometer (Agilent Technologies, Stockport, UK). The samples were mounted onto the surface of the germanium (Ge) crystal in the attenuated total reflection (ATR) assembly. FTIR spectra were recorded in the middle infrared range $\left(4000-500 \mathrm{~cm}^{-1}\right)$ with a resolution of $4 \mathrm{~cm}^{-1}$ in the absorbance mode for 40 scans at room temperature.

\subsection{Solubility Studies}

The $\mathrm{pH}$ dependence of chitosan polymers aqueous solubility was evaluated at room temperature by turbidimetry [39]. Each polymer $(50 \mathrm{mg})$ was dissolved in $10 \mathrm{~mL}$ of aqueous acetic acid $(10 \% v / v)$ and stirred for $1 \mathrm{~h}$; the $\mathrm{pH}$ level of the solutions was adjusted using $\mathrm{NaOH}$ solution $(5 \mathrm{M})$. Measurements were repeated after each stepwise addition of $\mathrm{NaOH}$ until reaching $\mathrm{pH}$ 12. The transmittance of the solution was recorded on a Nicolet e-100 spectrophotometer (Thermo Fisher Scientific, Warrington, UK) using a quartz cell with an optical path length of $1 \mathrm{~cm}$ at $\lambda 600 \mathrm{~nm}$, and the $\mathrm{pH}$ was measured using an FE20 $\mathrm{pH}$ meter (Mettler Toledo, Greifensee, Switzerland).

\subsection{In Vitro Inhibition of Acid Demineralisation}

Mineralized surfaces were prepared as follows: hydroxyapatite (HA, $2 \mathrm{~g}$ ) powder was suspended in acetone $(200 \mathrm{~mL})$, and $60 \mu \mathrm{L}$ aliquots of the homogenous suspension were transferred to each well of a 96 well plate. The plate was shaken $(50 \mathrm{rpm}$, microplate mixer SciQuip, Newtown, UK) at room temperature until the acetone was completely evaporated [40]. After drying, loose HA was removed by washing with deionized water $(5 \times)$ and plates were allowed to dry overnight. Any plate showing poor coverage and cracking was discarded, and the coated plates were sealed until further use. Before each experiment, the plates were rehydrated with deionized water for $1 \mathrm{~h}$. A phosphate standard calibration curve was prepared using $\mathrm{KH}_{2} \mathrm{PO}_{4}$ solutions with concentrations of phosphorus in the range $10-60 \mathrm{mg} \mathrm{L}^{-1}$ (or $0.32-1.94 \mathrm{mM}$ ). Deionized water and sodium fluoride were used as negative and positive controls, respectively. The positive control (sodium fluoride) solutions were prepared in deionized water in three different final concentrations: $\mathrm{NaF}_{\text {low }}(362.5 \mathrm{ppm}), \mathrm{NaF}_{\text {med }}(725 \mathrm{ppm})$, and $\mathrm{NaF}_{\text {high }}(1450 \mathrm{ppm})$. The polymer samples $(200 \mu \mathrm{L}, 1.0 \% w / v)$ were prepared in $0.2 \%$ acetic acid and the $\mathrm{pH}$ of all sample solutions was adjusted to $6.0 \pm 0.1$. Test solutions $(200 \mu \mathrm{L})$ were added to each well and agitated (50 rpm) at room temperature for $30 \mathrm{~min}$. After exposure to the test solutions, the wells were rinsed with deionized water $(5 \times)$, and $200 \mu \mathrm{L}$ of the erosive solution $(0.1 \mathrm{M}$ aqueous acetate buffer, $\mathrm{pH}$ 4.0, Alfa Aesar, Heysham, UK) was added to each well and agitated (50 rpm, $60 \mathrm{~min})$. Aliquots $(50 \mu \mathrm{L})$ were transferred into new microplates and mixed with $50 \mu \mathrm{L}$ vanadomolybdate reagent for 5 min before reading the UV absorbance at $450 \mathrm{~nm}$ (SpectraMax i3x, Molecular Devices, Berkshire, UK).

\subsection{Preparation of Bacterial Cultures}

Staphylococcus aureus (ATCC $25923^{\mathrm{TM}}$ ) was stored in Luria Bertani (LB) broth and sterile glycerol $30 \%$ (1:1) in a cryovial at $-80{ }^{\circ} \mathrm{C}$. The loop shalt of Culti-Loops ${ }^{\mathrm{TM}}$ Streptococcus mutans (ATCC $25175^{\mathrm{TM}}$ ) was cut from the handle using sterile scissors and dropped into 
warm Brain Heart Infusion (BHI, 0.5 to $1.0 \mathrm{~mL}$, Oxoid, Basingstoke, UK) and incubated at $37^{\circ} \mathrm{C}$ in a $5 \% \mathrm{CO}_{2}$ atmosphere overnight. Bacteria were then streaked onto blood agar (Oxoid, Basingstoke, UK) plates using sterile cotton swabs and incubated at $37{ }^{\circ} \mathrm{C}$ in $5 \%$ $\mathrm{CO}_{2}$ for 24-48 h. Two to three single colonies were taken from the plate with a sterile loop and dispersed in $5 \mathrm{~mL}$ of fresh $\mathrm{BHI}$ to be incubated overnight at $37{ }^{\circ} \mathrm{C}$ in $5 \% \mathrm{CO}_{2}$. The bacteria were stored at $-80{ }^{\circ} \mathrm{C}$ by mixing the overnight culture and sterile glycerol $30 \%(1: 1)$ in a cryovial. Before the experiment, the bacteria were transferred from $-80{ }^{\circ} \mathrm{C}$ into $5 \mathrm{~mL}$ of fresh sterile $\mathrm{BHI}$ medium by a sterile tip and incubated at $37{ }^{\circ} \mathrm{C}$ (in $5 \% \mathrm{CO}_{2}$ atmosphere for $S$. mutans) overnight until the medium reached an optical density at $600 \mathrm{~nm}$ $\left(\mathrm{OD}_{600}\right)$ of 0.5 .

\subsection{Determination of Minimum Inhibitory Concentration (MIC) and Minimum Bactericidal Concentration (MBC)}

Overnight bacterial suspensions $(100 \mu \mathrm{L})$ were transferred into $5 \mathrm{~mL}$ of fresh sterile medium and incubated again until $\mathrm{OD}_{600}=0.5$. Serial dilutions of the polymer solutions from stock ( $5 \mathrm{mg} \mathrm{mL}^{-1}$ in $1 \%$ acetic acid) were tested at final concentrations $0.1,0.2,0.4,0.8$, $1.2,1.6,2.0,3.2$, and $4.0 \mathrm{mg} \mathrm{mL}^{-1}$ in medium. One hundred microliters of each polymer solution were placed into the well containing $5 \mu \mathrm{L}$ of the bacterial suspensions. Wells containing only culture medium and bacteria were used as a negative control. Turbidity measurements were made for all the wells after $24 \mathrm{~h}$ of incubation at $37^{\circ} \mathrm{C}$ for $\mathrm{S}$. aureus and at $37^{\circ} \mathrm{C}$ under anaerobic condition $\left(5 \% \mathrm{CO}_{2}\right)$ for $S$. mutans. The MIC of each bacteria was recorded at $600 \mathrm{~nm}$ as the lowest concentration of each polymer that inhibited the bacterial growth, as detected by the absence of visual turbidity [41]. The MIC was determined as the lowest concentration of each polymer that restricted growth to a level below an $\mathrm{OD}_{600}$ of $\leq 0.05$ [42]. The MBC was defined as the lowest concentration of test compounds that prevented any visible growth on agar plates. Samples of $20 \mu \mathrm{L}$ were transferred from clear wells into LB agar plates, and they were incubated at $37^{\circ} \mathrm{C}$ for $24 \mathrm{~h}$ for $S$. aureus and into blood agar plates for $48 \mathrm{~h}$ in $5 \% \mathrm{CO}_{2}$ for $S$. mutans. All experiments were performed in triplicate.

\subsection{Inhibition of S. mutans Biofilm Formation}

One hundred microliters of $S$. mutans suspension were transferred to $5 \mathrm{~mL}$ of prewarmed fresh $\mathrm{BHI}$ medium and incubated at $37^{\circ} \mathrm{C}$ in a $5 \% \mathrm{CO}_{2}$ to $\mathrm{OD}_{600} \approx 0.5$. This culture $(100 \mu \mathrm{L})$ was then dispensed into 48 well plates, and to this biofilm medium $(\mathrm{BM}, 700 \mu \mathrm{L}$ for negative control) or polymer solution $(700 \mu \mathrm{L})$ in Biofilm Medium (BM) at different concentrations $(0.1,0.2,0.4,0.8$, and $1.2 \mathrm{mg} / \mathrm{mL})$ was added. Controls with $800 \mu \mathrm{L}$ of BM without bacteria were also prepared. Preparation of BM was undertaken as previously described [43]. Plates were incubated for $24 \mathrm{~h}$ at $37^{\circ} \mathrm{C}$ in a $5 \% \mathrm{CO}_{2}$ atmosphere without agitation. After overnight incubation, the formation of biofilm was quantified by crystal violet assay [43].

\subsection{Formulation of Chitosan-Based Mouthwash}

The chitosan-based mouthwash formulas are summarized in Table 1. Lutrol (poloxamer 407$)$ solution $(4 \% w / v)$ was prepared in water, while polymers were dissolved in $0.5 \mathrm{M}$ acetic acid. Three separate batches were prepared; all the ingredients were solubilized at room temperature and the $\mathrm{pH}$ of the mouthwash was adjusted to $5.5 \pm 0.1$ with $\mathrm{NaOH}$ (1 M). 
Table 1. Chitosan-based mouthwash formulation.

\begin{tabular}{|c|c|c|c|}
\hline \multirow{2}{*}{ Ingredients } & \multicolumn{2}{|c|}{ Quantity } & \multirow{2}{*}{ Function } \\
\hline & Formula I & Formula II & \\
\hline Glycerin & $5 \mathrm{~g}$ & $5 \mathrm{~g}$ & Humectant \\
\hline Sodium saccharin & $450 \mathrm{mg}$ & $450 \mathrm{mg}$ & Sweetener \\
\hline Lutrol $4 \% w / v$ & $50 \mathrm{~mL}$ & $50 \mathrm{~mL}$ & Surfactant \\
\hline Polymer & $0.2 \mathrm{mg}$ & $0.2 \mathrm{mg}$ & Anti-biofilm \\
\hline Acetic acid (0.5 M) & $1 \mathrm{~mL}$ & $1 \mathrm{~mL}$ & $\begin{array}{c}\text { Acidity } \\
\text { modifier/co-solvent }\end{array}$ \\
\hline Food blue & - & $0.2 \mathrm{~mL}$ & Coloring agent \\
\hline Peppermint oil & - & $0.25 \mathrm{~mL}$ & Flavoring agent \\
\hline Ethanol & - & $20 \mathrm{~mL}$ & Co-solvent \\
\hline Water & to $100 \mathrm{~mL}$ & to $100 \mathrm{~mL}$ & Vehicle \\
\hline
\end{tabular}

\subsection{Evaluation of Mouthwash Stability}

Samples were stored at 25 or $40^{\circ} \mathrm{C}$ for six months with eight sampling points $(0,3,7,14$, $21,30,90$, and 180 days) in $7 \mathrm{~mL}$ sample vials made of neutral glass (Type IB) and closed with polypropylene screw caps (Fisher Scientific, Loughborough, UK). Organoleptic properties such as color, odor, and appearance were monitored. Color intensity was measured by UV spectroscopy (Multiskan Go UV-VIS spectrophotometer, Thermo Fisher Scientific, Paisley, UK) at wavelengths ranging from 300 to $700 \mathrm{~nm}$. Odor was subjectively assessed by the investigator. The $\mathrm{pH}$ was measured with a digital $\mathrm{pH}$ meter (Accumet AB150, Fisher Scientific, Loughborough, UK). For each sample, three independent measurements were performed, and data were reported as the mean of the replicates. $\mathrm{pH}$ values from the stability data were analyzed using a two-way analysis of variance (ANOVA) with Tukey's and Sidak post-test with an a priori level significance of 0.05 to detect statistically significant differences between the time and temperature from the mouthwash formulations and control. Sedimentation was visually assessed after centrifuging $1 \mathrm{~mL}$ of each sample at $5000 \mathrm{rpm}$ for $5 \mathrm{~min}$ [44] at room temperature using a Jouan B4i Centrifuge (Hemel Hampstead, UK). In vitro anti-biofilm activity was tested as described above, at all timepoints of the stability study.

\subsection{Biofilm Removal Efficacy}

In vitro anti-biofilms activity was performed on overnight $S$. mutans biofilms on 48 well-plates. The S. mutans biofilms were prepared as described in Section 2.9. After overnight incubation at $37^{\circ} \mathrm{C}$ in a $5 \% \mathrm{CO}_{2}$ atmosphere without agitation, the plate was blotted on a paper towel to remove the culture media, and the wells were washed with distilled water to remove loosely bound cells, and the plate blotted again on a paper towel to remove all liquid. This step was repeated twice, and the plate was air-dried. Mouthwash $(100 \mu \mathrm{L})$ was added into the well for $30 \mathrm{~s}$ with gentle shaking. The fluid was removed, washed with deionized water, and the well was air-dried before the addition of $50 \mu \mathrm{L}$ of $0.1 \%$ crystal violet into each well. After 15 min, crystal violet was removed, and the wells were washed with deionized water twice. Acetic acid $(33 \%, 200 \mu \mathrm{L})$ was added into each well before measuring the absorbance at $575 \mathrm{~nm}$. Chlorhexidine $0.2 \%$ mouthwash and Listerine ${ }^{\circledR}$ mouthwash were used as the positive controls and sterile water as a negative control.

\subsection{Cytocompatibility Studies}

Cell cytocompatibility was quantitatively measured by MTT assay using primary human gingival fibroblast (HGF-1 ATCC-CRL-2014) cells (P 7-8) derived from adult gingival tissue (ATCC, Middlesex, UK) [45,46]. Cells were cultured in DMEM (ATCC-30-2002) containing 10\% FBS (FBS, ATCC-30-2025) and 1\% penicillin/streptomycin (Fisher Scientific, Loughborough, UK). Mouthwash formulations were prepared as described above, but without adding the dye to avoid interference. In this experiment, artificial saliva [47] was 
used as a negative control; Listerine ${ }^{\circledR}$ total care (a commercially available mouthwash) and $0.2 \%$ CHX Minosep ${ }^{\circledR}$ mouthwash (a potent anti-plaque mouthwash) were used as the positive control. Briefly, fibroblasts were plated at a density of $5 \times 10^{3}$ cells per well in 96-well microtiter plates, and after $24 \mathrm{~h}$ of incubation, the cells were exposed to $100 \mu \mathrm{L}$ of treatment solution (mouthwash or control) for 30 or $60 \mathrm{~s}$. Afterwards, MTT $\left(5 \mathrm{mg} \mathrm{mL}^{-1}\right)$ was dissolved in PBS, added to a final concentration of $0.5 \mathrm{mg} \mathrm{mL}^{-1}$ to each well, and incubated for further $4 \mathrm{~h}$. After removing the MTT/medium, the purple formazan crystals were dissolved in $100 \mu \mathrm{L}$ of DMSO and absorbance was measured at $570 \mathrm{~nm}$ and $690 \mathrm{~nm}$ as the background reference on a micro-plate reader SpectraMax i3x (Molecular Devices, Berkshire, UK).

\subsection{Statistical Analysis}

The results were expressed as the mean \pm standard deviation (SD) for a triplicate at least, unless otherwise specified. Statistical significance was tested using GraphPad Prism version 8.2.1 for Windows (GraphPad Software, San Diego, CA USA, www.graphpad.com (accessed on 21 February 2022)).

\section{Results}

\subsection{Preparation and Characterisation of Fluoridated Polymers}

A preliminary study was conducted by loading fluoride ions onto CS3H by dialysis against sodium fluoride solutions (low against $362.5 \mu \mathrm{g} \mathrm{mL} \mathrm{m}^{-1}$, medium against $725 \mu \mathrm{g} \mathrm{mL} \mathrm{m}^{-1}$, and high against $1450 \mu \mathrm{g} \mathrm{mL}^{-1}$ ) for $24 \mathrm{~h}$.

The fluoride loading capacity increased with the concentration of fluoride in the dialysis solution (Figure 1), while the fluoride entrapment efficiency (FEE) showed the opposite behavior. CS3H Lys was dialyzed against a $725 \mu \mathrm{g} \mathrm{mL} \mathrm{m}^{-1} \mathrm{NaF}$ solution and its fluoride loading capacity was $104.26 \pm 2.17 \mu \mathrm{g} \mathrm{mL}^{-1}$ with FEE equal to $29.29 \pm 0.60 \%$. The dependence of the water solubility of polymers on $\mathrm{pH}$ was investigated by a turbidity assay, in which the light transmittance was correlated with the water solubility. All polymers showed a decreasing solubility with increasing $\mathrm{pH}$, as previously reported for chitosan polymers in the literature [48,49]. However, the formation of the fluoride ion significantly enhanced the solubility of chitosan $(\mathrm{CS3H})$ at all $\mathrm{pH}$ values (Table 2). Fluoridation of CS3H Lys resulted in significantly higher solubility at a neutral $\mathrm{pH}$. The FTIR spectra showed that no chemical modification of CS3H Lys occurs following dialysis with NaF (Figure 2), confirming loading is only by ionic interaction [50].
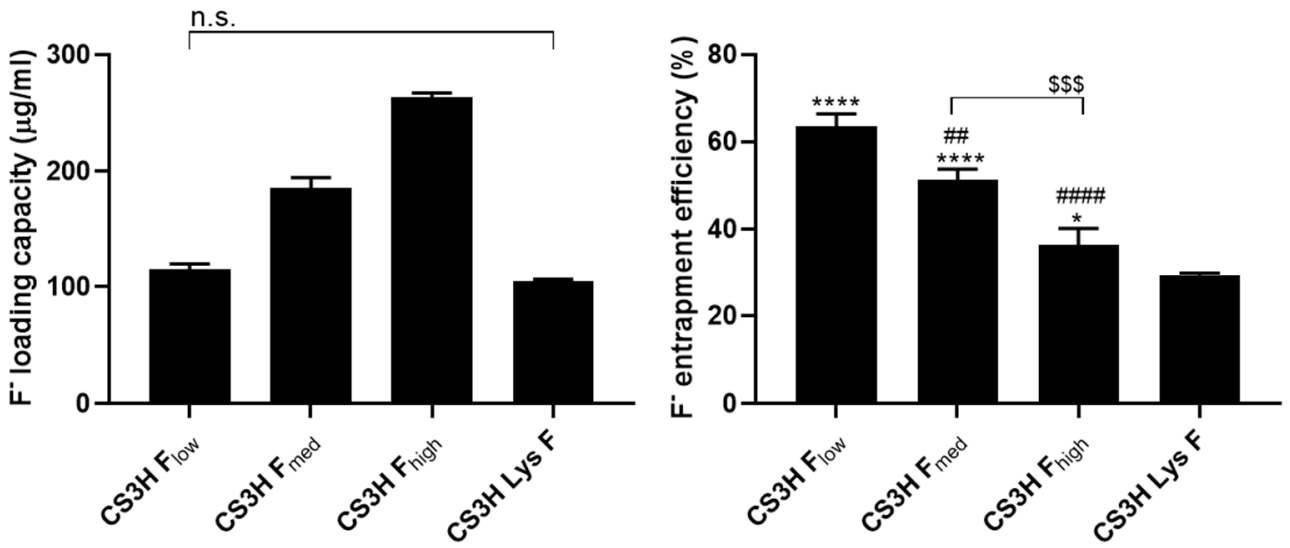

Figure 1. Fluoride ions loading capacity and entrapment efficiency by chitosan polymers. Data are reported as mean $\pm \mathrm{SD}, \mathrm{n}=3$. One-way ANOVA returned $p<0.0001$ for both sets of data, the results of the Tukey's multi-comparison test are shown in the graphs. For loading capacity, all comparisons returned a $p<0.0001$ unless otherwise indicated. For entrapment efficiency, ${ }^{*} p<0.05$, ***** $p<0.0001$ compared to CS3H Lys F, \#\# $p<0.01$, \#\#\#\# $p<0.0001$ compared to CS3H Flow and $\$ \$ p<0.001$ comparison as specified on graph. 
Table 2. $\mathrm{pH}$ dependence of aqueous solubility of fluoridated polymers. Data are reported as mean $\pm \mathrm{SD}, \mathrm{n}=3$. One-way ANOVA followed by Tukey's multi-comparison test was performed to assess the effect of fluoridation with different amounts of fluoride ions on the solubility of CS3H (** $p<0.01$; ${ }^{* * *} p<0.001$, and ${ }^{* * * *} p<0.0001$ compared to CS3H; ${ }^{a} p<0.05$ and $^{\mathrm{b}} p<0.01$ comparing polymers annotated with the same letter). Unpaired, two-tailed $t$-test was performed to assess the effect of fluoridation on the solubility of CS3H Lys ( $p<0.05$; ${ }^{\# \#} p<0.01$; ${ }^{\# \# \#} p<0.001$ ).

\begin{tabular}{ccccc}
\hline \multirow{2}{*}{ Polymers } & \multicolumn{4}{c}{ Transmittance (\%) } \\
\cline { 2 - 5 } & $\mathbf{p H ~ 6 . 0 0}$ & $\mathbf{p H ~ 6 . 5 0}$ & $\mathbf{p H ~ 7 . 0 0}$ & pH 7.25 \\
\hline CS3H & $98.04 \pm 0.44$ & $97.72 \pm 0.13$ & $69.15 \pm 3.5$ & $29.06 \pm 3.20$ \\
CS3H F $_{\text {low }}$ & $99.34 \pm 0.13^{* *}$ & $99.51 \pm 0.04^{* * *}$ & $88.32 \pm 4.81^{* * * a}$ & $72.47 \pm 5.64^{* * * *}$ \\
CS3H F $_{\text {medium }}$ & $99.80 \pm 0.20^{* * *}$ & $99.34 \pm 0.19^{* * *}$ & $97.30 \pm 1.46^{* * * * a b}$ & $80.21 \pm 3.46^{* * * *}$ \\
CS3H F Figh $^{* * *}$ & $99.52 \pm 0.25^{* * *}$ & $99.46 \pm 0.34^{* * *}$ & $85.80 \pm 0.61^{* * * \mathrm{~b}}$ & $72.78 \pm 3.91^{* * * *}$ \\
CS3H Lys & $92.88 \pm 1.07^{*}$ & $92.71 \pm 0.26$ & $59.19 \pm 7.44$ & $25.22 \pm 3.34^{* \#}$ \\
CS3H Lys F & $88.45 \pm 1.89^{\#}$ & $88.67 \pm 1.43$ & $86.04 \pm 1.16^{\# \#}$ & $48.5 \pm 2.42^{\# \# \#}$ \\
\hline
\end{tabular}

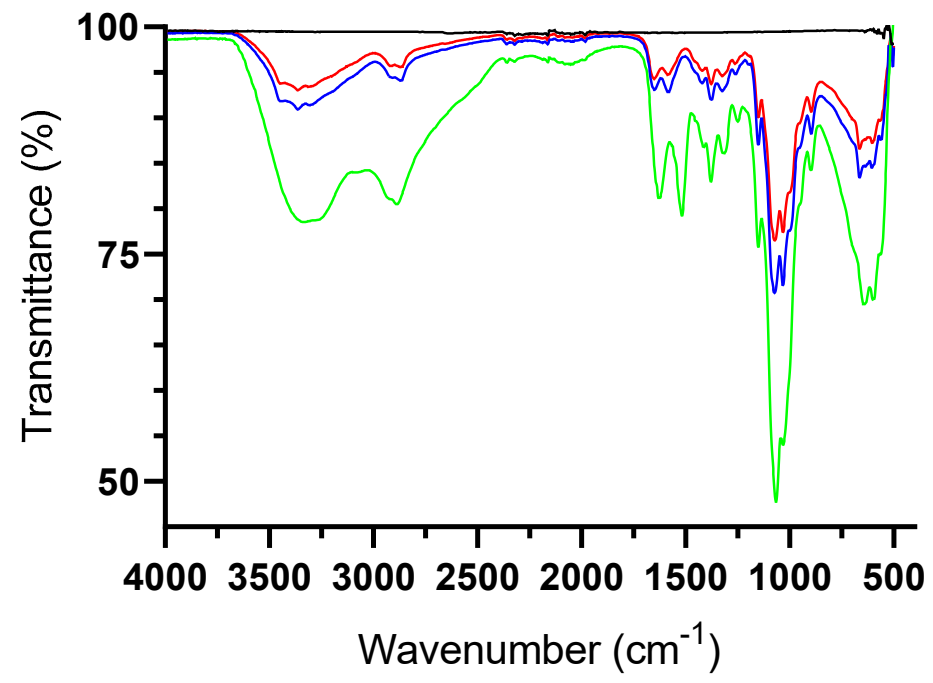

Figure 2. FTIR spectra of NaF (black), CS3H (green), CS3H Lys (blue), and CS3H Lys F (red).

\subsection{Inhibition of Acid Demineralisation In Vitro}

Dental erosion of the tooth normally occurs by the action of acid consumed through food and drink, or the acid products generated by the bacteria present in the mouth; as a result, phosphate ions are released [51]. For this reason, the quantification of phosphate release from hydroxyapatite deposits after acid exposure can be used in vitro to quantify the demineralization of tooth enamel due to acid attack and evaluate the protective action of dental products. The ability of $\mathrm{NaF}$ solutions to prevent the acid triggered demineralization of the HA was shown to increase proportionally to the concentration of the ions for the $\mathrm{NaF} 362.5$ and $725 \mu \mathrm{g} \mathrm{mL}{ }^{-1}$ concentration samples, but the higher concentration of $\mathrm{NaF}$ $\left(1450 \mu \mathrm{g} \mathrm{mL}^{-1}\right)$ showed no further significant increase (Figure 3). All polymers showed significant protection against acid challenge of the hydroxyapatite surfaces, but only CS3H $\mathrm{F}_{\text {high }}$ presented a significantly higher effect compared to CS3H (Figure 3). CS3H Lys F exhibited the highest activity with $58.57 \%$ of inhibition of phosphate release. 

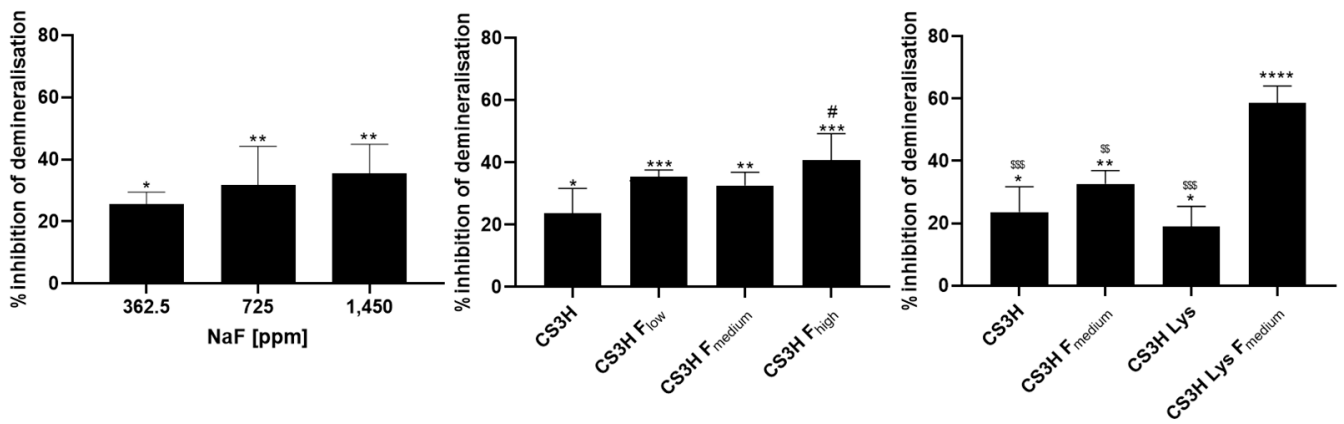

Figure 3. Inhibition of phosphate release by $\mathrm{NaF}$, chitosan, and its derivatives. Data are reported as mean $\pm \mathrm{SD}, \mathrm{n}=3$. Data were analyzed by one-way ANOVA followed by Tukey's multiple comparisons ${ }^{*} p<0.05,{ }^{* *} p<0.01,{ }^{* * *} p<0.001$ and ${ }^{* * * *} p<0.0001$ compared to deionized water; \# $p<0.05$, compared to CS3H; $\$$ \$ $p<0.01, \$ \$ \$<0.001$ compared to CSH3 Lys F $_{\text {medium}}$ ).

\subsection{Determination of $M I C$ and $M B C$}

The potential antibacterial activity of the modified chitosans was determined against S. aureus and S. mutans. All chitosan polymers were capable of inhibiting the growth of the microorganisms tested, with no significant difference between samples (Table 3).

Table 3. Values of MIC and MBC for the chitosan and modified chitosan against S. aureus and $S$. mutans. Data are reported as mean \pm SD $(n=4)$. Data were analyzed by two-way ANOVA followed by Dunnett's multiple comparisons. No significant difference was observed.

\begin{tabular}{ccccc}
\hline \multirow{2}{*}{ Polymer } & \multicolumn{2}{c}{ Staphylococcus aureus } & \multicolumn{2}{c}{ Streptococcus mutans } \\
\cline { 2 - 5 } & MIC $(\mathbf{m g} / \mathbf{m L})$ & MBC $(\mathbf{m g} / \mathbf{m L})$ & MIC $(\mathbf{m g} / \mathbf{m L})$ & MBC $(\mathbf{m g} / \mathbf{m L})$ \\
\hline CS & $1.60 \pm 0.33$ & $\geq 3.0$ & $1.50 \pm 0.20$ & $\geq 3.0$ \\
CS3H & $1.10 \pm 0.38$ & $\geq 3.0$ & $1.30 \pm 0.20$ & $\geq 3.0$ \\
CS3H Lys & $1.10 \pm 0.60$ & $\geq 3.0$ & $1.40 \pm 0.23$ & $\geq 3.0$ \\
CS3H Lys F & $1.40 \pm 0.23$ & $\geq 3.0$ & $1.40 \pm 0.23$ & $\geq 3.0$ \\
\hline
\end{tabular}

\subsection{Inhibition of Biofilms Formation}

Polymers were further studied for their potential to inhibit $S$. mutans biofilm formation (Figure 4). All polymers were able to completely prevent biofilm formation at the highest concentration tested, with more than $70 \%$ efficacy showed at the lowest concentration $\left(0.1 \mathrm{mg} \mathrm{mL}^{-1}\right)$. At all concentrations, the modified chitosans were significantly more active than $\mathrm{CS} 3 \mathrm{H}$, with a higher activity demonstrated by the non-fluoridated lysine derivative. CS showed a dose dependent effect with very significant reduction in viability caused by increasing concentrations ( $p<0.0001$ for all comparisons apart from 800 vs. 1200 that the $p$ value was $p<0.01)$. CS3H showed a dose dependent behavior $(p<0.001)$ up to $800 \mu \mathrm{gL}^{-1}$. CS3H Lys was highly effective with no statistical difference between concentrations above $200 \mu \mathrm{g} \mathrm{mL}^{-1}(p>0.05)$, while no more decrease in viability was noticed with CS3H Lys F from $400 \mu \mathrm{g} \mathrm{mL} \mathrm{m}^{-1}(p>0.05)$. 


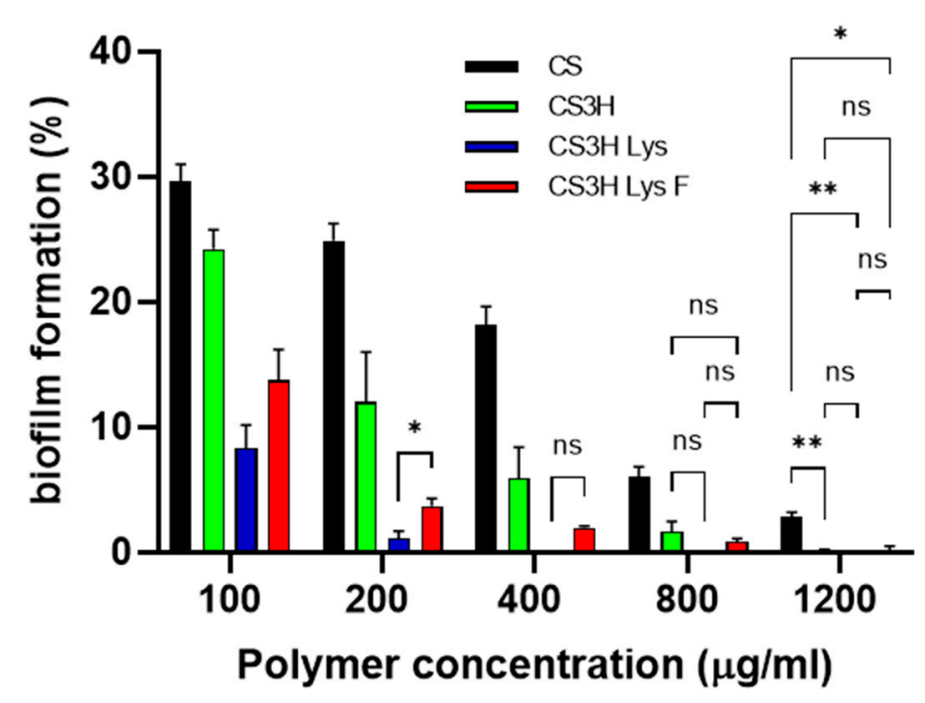

Figure 4. Effect of chitosan polymers on the growth of $S$. mutans biofilms. Data are reported as mean $\pm \mathrm{SD}, \mathrm{n}=6$. Data were analyzed by two-way ANOVA (both polymer and concentration effect returned $p<0.0001$ ) followed by Tukey's multiple comparisons; all comparisons between polymers at different concentrations returned $p<0.001$ unless otherwise indicated in the graph; ${ }^{*} p<0.05$; ** $p<0.001 ;$ ns $=$ non-significant.

\subsection{Cytocompatibility Study}

The cytocompatibility of the mouthwash formulations was assessed against human gingival fibroblasts (HGF). Mouthwash formulations were compared against artificial saliva as the negative control and Listerine ${ }^{\circledR}$ and $\mathrm{CHX}$ as the positive controls, and formulations were applied in their original concentration (Figure 5A) and diluted 1:1 with artificial saliva (Figure 5B) and applied for 30 and $60 \mathrm{s.}$
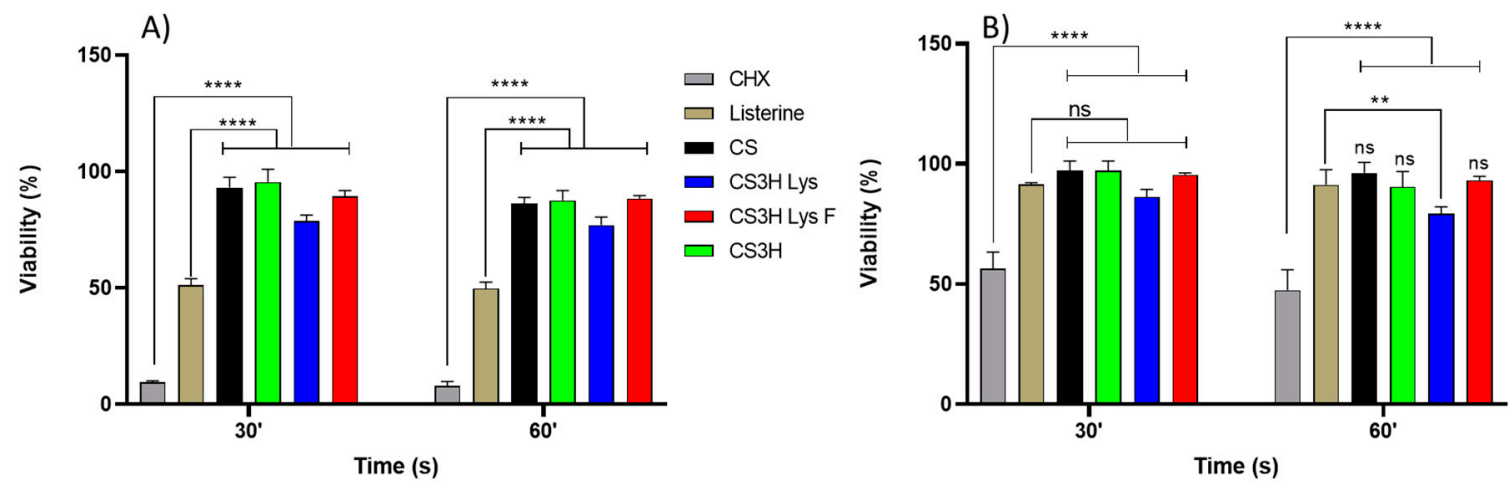

Figure 5. Cytocompatibility test on HGF cells of undiluted mouthwashes (A) and mouthwashes diluted 1:1 $v / v$ with artificial saliva $(B)$. Data are given as mean $\pm S D, n=4)$. Data were analysed by two-way ANOVA followed by Dunnett's multiple comparisons $\left({ }^{* *} p<0.01\right.$; ${ }^{* * * *} p<0.0001$ ); ns = non-significant.

The result of this study was in agreement with previous studies that reported that $\mathrm{CHX}$ has dose-dependent cytotoxic effects on cultured gingival cells [52,53]. Listerine ${ }^{\circledR}$ and $0.2 \%$ CHX showed cytotoxic effects on gingival fibroblasts with a mean viability of $51.1 \pm 2.9 \%$ and $9.4 \pm 0.7 \%$, respectively, after exposure for $30 \mathrm{~s}$, and $49.8 \pm 2.8 \%$ and $7.8 \pm 1.9 \%$, respectively, after exposure for $60 \mathrm{~s}$ (Figure 5A). The percentage cell viability increased significantly ( $80 \%$ for Listerine ${ }^{\circledR}$ and $50 \%$ for CHX) after dilution with artificial saliva (1:1). The increase in treatment time of mouthwashes did not induce a significant decrease in the percentage of HGF cell viability for both non-diluted and diluted-mouthwashes. 
The MTT test revealed that all chitosan mouthwashes maintained a higher percentage of viable cells compared to the positive control solutions $(p \leq 0.0001)$ (Figure 5$)$ for both undiluted and diluted mouthwashes.

\subsection{Stability Studies of Mouthwash Formulations}

The formulation and preparation of any new pharmaceutical or consumer care product necessitates adequate physical and chemical stability, as well as a microbiological profile unaltered over the period of time in storage under the influence of a variety of environmental factors, such as temperature, humidity, and light [54-56]. In this study, we evaluated the behavior of the formulations at 25 and $40{ }^{\circ} \mathrm{C}$ for 6 months.

\subsubsection{Organoleptic Properties}

Visually, both mouthwashes presented a consistent color and clear appearance with no turbidity and a peppermint odor (subjective evaluation) that was unaltered for up to 180 days of storage both at 25 and $40{ }^{\circ} \mathrm{C}$.

Color stability was also determined by UV measurements and changes to the absorbance values at $\lambda_{\max } 639 \mathrm{~nm}$ were evaluated. No statistical difference in absorbance was identified for samples stored at the two different temperatures (Figures S4-S7 and Table 4). Mouthwashes containing CS3H and CS3H Lys did not undergo any changes in absorbance for the duration of the experiment, while CS3H Lys F mouthwash showed an initial change that was reversed in time until the end of the experiment.

Table 4. Results of the statistical evaluation of absorbance values at $639 \mathrm{~nm}$ of different mouthwash formulations over time and at different temperatures. Two-way ANOVA was performed, followed by Sidak's multiple comparisons test to see the effect of the temperature on the absorbance of the dye in the mouthwash formulation. The data were rerun with Dunnett's multiple comparisons test to see the effect of the time (ns = not significant or $p>0.05 ;{ }^{*} p \leq 0.05 ;{ }^{* *} p \leq 0.01$ ).

\begin{tabular}{cccc}
\hline Polymer & $25{ }^{\circ} \mathbf{C}$ & $\mathbf{4 0}{ }^{\circ} \mathbf{C}$ & $25^{\circ} \mathbf{C}$ vs. $40^{\circ} \mathbf{C}$ \\
\hline CS & $\mathrm{T}_{0}$ vs. $\mathrm{T}_{90}\left(^{* *}\right)$ & $\mathrm{T}_{0}$ vs. $\mathrm{T}_{3}\left(^{*}\right)$ & $\mathrm{ns}$ \\
CS3H & $\mathrm{T}_{0}$ vs. $\mathrm{T}_{180}\left(^{*}\right)$ & $\mathrm{ns}$ & $\mathrm{ns}$ \\
CS3H Lys & $\mathrm{ns}$ & $\mathrm{ns}$ & $\mathrm{ns}$ \\
CS3H Lys F & $\mathrm{ns}$ & $\mathrm{ns}$ & $\mathrm{ns}$ \\
\hline
\end{tabular}

\subsubsection{Evaluation of $\mathrm{pH}$ Stability}

As part of the stability study, the $\mathrm{pH}$ values of the different formulations were recorded over time (Table 5 and Table S2), and the $\mathrm{pH}$ remained unaltered by time or temperature.

Table 5. The effect of temperature on the $\mathrm{pH}$ of chitosan mouthwash formulation. Data are expressed as mean $\pm \mathrm{SD}, \mathrm{n}=3$. Two-way ANOVA followed by Sidak's test was carried out ${ }^{*} p<0.05$ compared to $\mathrm{T}_{0}$ ).

\begin{tabular}{cccccc}
\hline Polymer & Temp & $\mathbf{T}_{\mathbf{0}}$ & $\mathbf{T}_{\mathbf{3 0}}$ & $\mathbf{T}_{\mathbf{9 0}}$ & $\mathbf{T}_{\mathbf{1 8 0}}$ \\
\hline \multirow{2}{*}{$\mathrm{CS}$} & $25^{\circ} \mathrm{C}$ & \multirow{2}{*}{$5.54 \pm 0.02$} & $5.56 \pm 0.02$ & $5.54 \pm 0.02$ & $5.53 \pm 0.02$ \\
& $40^{\circ} \mathrm{C}$ & & $5.53 \pm 0.02$ & $5.52 \pm 0.01$ & $5.52 \pm 0.03$ \\
\hline \multirow{2}{*}{$\mathrm{CS3H}$} & $25^{\circ} \mathrm{C}$ & \multirow{2}{*}{$5.52 \pm 0.03$} & $5.53 \pm 0.01$ & $5.52 \pm 0.01$ & $5.52 \pm 0.01$ \\
& $40^{\circ} \mathrm{C}$ & & $5.50 \pm 0.01$ & $5.52 \pm 0.01$ & $5.50 \pm 0.01$ \\
\hline \multirow{2}{*}{$\mathrm{CS3H} \mathrm{Lys}$} & $25^{\circ} \mathrm{C}$ & \multirow{2}{*}{$5.52 \pm 0.01$} & $5.52 \pm 0.02$ & $5.52 \pm 0.02$ & $5.52 \pm 0.02$ \\
& $40^{\circ} \mathrm{C}$ & & $5.48 \pm 0.01 *$ & $5.48 \pm 0.03$ & $5.48 \pm 0.02$ \\
\hline \multirow{2}{*}{$\mathrm{CS3H} \mathrm{Lys} \mathrm{F}$} & $25^{\circ} \mathrm{C}$ & \multirow{2}{*}{$5.52 \pm 0.02$} & $5.54 \pm 0.06$ & $5.54 \pm 0.04$ & $5.53 \pm 0.05$ \\
& $40^{\circ} \mathrm{C}$ & & $5.50 \pm 0.04$ & $5.52 \pm 0.06$ & $5.51 \pm 0.03$ \\
\hline
\end{tabular}




\subsubsection{Sedimentation}

The appearance of each formulation was visually examined before and after sample centrifugation ( $5000 \mathrm{rpm}$ for $5 \mathrm{~min}$ ). No separation was observed for any of the formulations at either storage temperatures.

\subsubsection{Biofilm Removal Efficacy over Time}

The effect of chitosan mouthwashes on S. mutans biofilms was observed using crystal violet staining for the duration of the stability study in order to ascertain that the mouthwash efficacy was maintained (Figure 6).
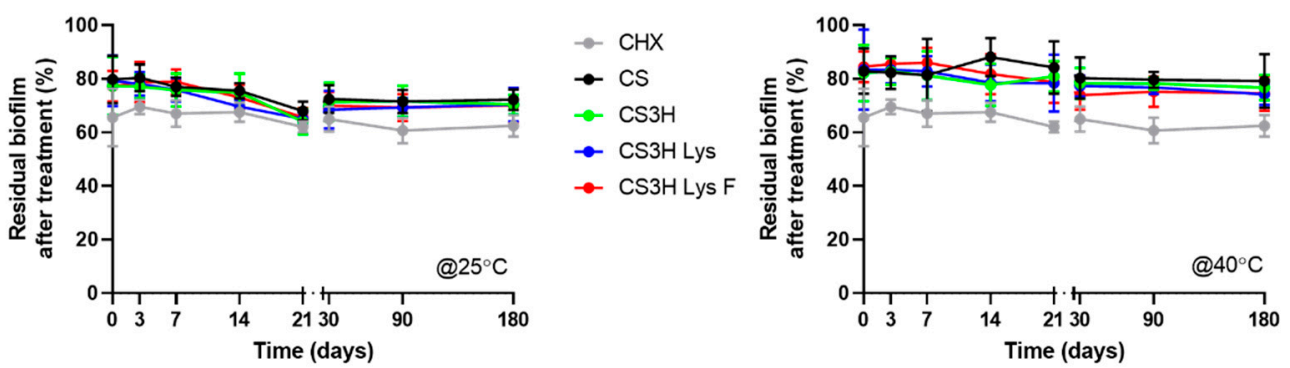

Figure 6. Effect of mouthwashes stored at 25 and $40{ }^{\circ} \mathrm{C}$ for up to 6 months on S. mutans biofilm formation. Data are reported as mean $\pm \mathrm{SD}, \mathrm{n}=9$. Two-way ANOVA: polymer effect $p<0.0001$, time effect $p<0.0001$, polymer and time $p>0.05$.

At time zero, for the samples stored at $25^{\circ} \mathrm{C}$, the control $\mathrm{CHX}$ solution was as effective as all our mouthwash preparations at reducing the formation of $S$. mutans biofilm $(p>0.05$, Tukey's multi-comparison test). A similar performance to CHX was maintained by CS3H Lys $\mathrm{F}$ after 6 months $(p>0.05)$. When stored at $40{ }^{\circ} \mathrm{C}$, all formulations were statistically less effective compered to CHX $(p>0.05)$, however the CS3H Lys and CS3H Lys F formulations were more stable than the original chitosan $(p<0.05)$. The effect of temperature on biofilm reduction was further analyzed (Figure S8). Some statistical differences were observed, where the effect was higher at room temperature compared to the elevated temperature at specific time points, but no clear trend was identified, and, in all cases, efficacy was comparable at the two different temperatures after 6 months, confirming that the efficacy of the mouthwash formulations developed remained unaltered at both 25 and $40{ }^{\circ} \mathrm{C}$ for 6 months.

\section{Discussion}

Mouthwashes are designed to enhance daily oral hygiene routines by helping to minimize the formation of biofilm, and to prevent and control gingivitis, bad breath, and tooth decay. Their action is generally aided by the presence of antibacterial agents, sodium fluoride, and essential oils. Currently, chlorhexidine is the antibacterial gold standard, despite its disadvantages, such as tooth discoloration, promotion of calculus, and alteration of taste perception. Research to find new compounds with a high protective effect and anti-bacterial properties but lower toxicity than $\mathrm{CHX}$ is timely. It has been previously shown that positively charged chitosan chains have the ability to form protective layers on the tooth surface [57], so we combined this property with the remineralizing activity of fluoride ions, thus creating fluoridated chitosan compounds that have been prepared for the first time, to the best of our knowledge. Other studies have investigated the effect of the addition of chitosan in solution or as part of a paste formulation, and found that, while chitosan enhances the effects of fluoride compounds, it often does not have an antimicrobial effect in these formulations [58], and one of the reasons for this could be linked to the high molecular weight employed in these studies. As the main aim of adding chitosan to fluoride salts containing formulas is that of increasing the overall viscosity, high molecular weight chitosan are favored; these, however, have a lower solubility, require an acidic solvent, and have a lower antimicrobial activity [58,59]. Based on these previous findings, we prepared 
low molecular weight chitosan derivatives and formed fluoride salts using the protonated chitosan as the counterion. The fluoride content in commercial oral health preparations ranges from 200-250 ppm in mouthwashes to $1450 \mathrm{ppm}$ in consumer toothpastes, and up to $5000 \mathrm{ppm}$ in prescription oral products. We successfully loaded fluoride ions on both chitosan and $N$-(2(2,6-diaminohexanamide)-chitosan with CS3H Lys F, able to provide $1450 \mathrm{ppm}$ of $\mathrm{F}^{-}$if dissolved at concentrations lower than $0.1 \mathrm{mg}$ per $100 \mathrm{~mL}$. The fluoride salts of chitosan also showed a higher solubility at neutral $\mathrm{pH}$, allowing for the preparation of solutions at higher concentrations than the parent polymer. All of the polymers tested had a protective effect against acid demineralization, similar to that shown by NaF. Our results confirm the barrier action chitosan can have by forming a protective layer on the tooth surface [57], and also the ability to enhance the effect of fluoride ions by prolonging their contact with the tooth surface. In fact, CS3H Lys F was more effective than the highest dose of $\mathrm{NaF}$, even if it contained a concentration of fluoride ions that was more than 3000 times lower. This is supported by previous findings that indicate that efficient delivery of fluoride has a higher impact on the overall effectiveness of the treatment compared to the dose of fluoride used [60]. This means that the application of fluoridated chitosan has the potential to reduce the therapeutic dose of fluoride required. Previous studies found chitosan of a high and low molecular weight to have a MIC against $S$. mutants in the range of 3-5 mg mL $\mathrm{mL}^{-1}$ [58], while our derivatives have MIC values that are 3- to 5-fold lower. Furthermore, at concentrations as low as $200 \mu \mathrm{g} \mathrm{mL}^{-1}$, our derivatives were significantly more active compared to the starting chitosan, and at the same concertation, these chitosan derivatives were significantly less toxic than $\mathrm{CHX}$ (cell viability 8-fold higher). These results suggest that if we load less fluoride ions on the CS3H Lys, we can have satisfactory demineralization protection with negligible cell toxicity and higher antibacterial activity. We further developed mouthwash formulations containing CS3H Lys and CS3H Lys F, and the stability study showed that storage did not have a significant effect on color, odor, solubility of components, and $\mathrm{pH}$ of all mouthwash formulations for up to 6 months. Mouthwashes formulated with modified chitosan (CS3H Lys and CS3H Lys F) were more effective at reducing the viability of $S$. mutans, the main cariogenic bacteria, compared to the original chitosan mouthwash. This activity did not change significantly during storage, even at higher temperatures.

\section{Conclusions}

We successfully prepared, for the first time, fluoride salts of chitosan and $N-(2(2,6-$ diaminohexanamide)-chitosan. CS3H Lys F showed a higher ability to protect teeth from acid demineralization compared to NaF. The polymer also presented antimicrobial properties and cytocompatibility. The polymer can be further improved by reducing the quantity of loaded fluoride, which would allow for maintaining the protective action and enhance the antibacterial properties. This novel polymer can be formulated in stable mouthwash formulations, and future work could look at its inclusions in toothpastes that are more widely used.

Supplementary Materials: The following supporting information can be downloaded at: https:// www.mdpi.com/article/10.3390/pharmaceutics14030488/s1. Section S1 (Figures S1-S3 and Table 2: determination of fluoride. Figures S4-S7: UV spectra. Tables S2 and S3: the effect of temperature on $\mathrm{pH}$ of formulations. Figure S8: Effect of temperature on the percentage S. mutans biofilm formation in the presence of chitosan mouthwashes.

Author Contributions: Conceptualization, D.P.R., A.L. and M.R.; methodology, D.P.R.; formal analysis, D.P.R. and M.R.; investigation, D.P.R.; resources, data curation, D.P.R. and M.R.; writing—original draft preparation, D.P.R. and M.R.; writing—review and editing, D.P.R., R.D., A.L. and M.R.; supervision, A.L. and M.R.; funding acquisition, D.P.R. and M.R. All authors have read and agreed to the published version of the manuscript.

Funding: This research was funded by the Indonesian government through the Ministry of Research, Technology, and by the Higher of Education for financial support through the scholarship Program 
for Research and Innovation in Science and Technology (RISET-Pro) World Bank Loan No. 8245-ID. The APC was funded by the University of Portsmouth.

Institutional Review Board Statement: Not applicable.

Informed Consent Statement: Not applicable.

Data Availability Statement: All data relative to this study are included in the manuscript and Supplementary Materials.

Conflicts of Interest: The authors declare no conflict of interest.

\section{References}

1. WHO Oral Health. Available online: https://www.who.int/news-room/fact-sheets/detail/oral-health (accessed on 11 January 2022).

2. Alhabdan, Y.A.; Albeshr, A.G.; Yenugadhati, N.; Jradi, H. Prevalence of dental caries and associated factors among primary school children: A population-based cross-sectional study in Riyadh, Saudi Arabia. Environ. Health Prev. Med. 2018, 23, 60. [CrossRef] [PubMed]

3. Chu, C.H.; Wong, S.S.S.; Suen, R.P.C.; Lo, E.C.M. Oral health and dental care in Hong Kong. Surgeon 2013, 11, 153-157. [CrossRef] [PubMed]

4. Duangthip, D.; Gao, S.S.; Lo, E.C.M.; Chu, C.H. Early childhood caries among 5- to 6-year-old children in Southeast Asia. Int. Dent. J. 2017, 67, 98-106. [CrossRef] [PubMed]

5. Chandki, R.; Banthia, P.; Banthia, R. Biofilms: A microbial home. J. Indian Soc. Periodontol. 2011, 15, 111-114. [CrossRef]

6. Nazir, R.; Zaffar, M.R.; Amin, I. Chapter 8-Bacterial Biofilms: The Remarkable Heterogeneous Biological Communities and Nitrogen Fixing Microorganisms in Lakes; Elsevier Inc.: Amsterdam, The Netherlands, 2019; ISBN 978-0-12-817495-1.

7. Marsh, P.D. Dental plaque as a biofilm and a microbial community-Implications for health and disease. BMC Oral Health 2006, 6 , 1-7. [CrossRef]

8. Ahn, S.J.; Ahn, S.J.; Wen, Z.T.; Brady, J.; Burne, R.A. Characteristics of biofilm formation by Streptococcus mutans in the presence of saliva. Infect. Immun. 2008, 76, 4259-4268. [CrossRef]

9. Swamy, M.K.; Akhtar, M.S.; Sinniah, U.R. Antimicrobial properties of plant essential oils against human pathogens and their mode of action: An updated review. Evid.-Based Complement. Altern. Med. 2016, 2016, 3012462. [CrossRef]

10. NHS How to Keep Your Teeth Clean. Available online: https://www.nhs.uk/live-well/healthy-body/how-to-keep-your-teethclean/ (accessed on 11 January 2022).

11. Van Loveren, C.; Buijs, J.F.; Ten Cate, J.M. The effect of triclosan toothpaste on enamel demineralization in a bacterial demineralization model. J. Antimicrob. Chemother. 2000, 45, 153-158. [CrossRef]

12. Riley, P.; Lamont, T. Triclosan produces statistically significant reduction in plaque, gingivitis and caries but not clinically important benefit. Evid. Based. Dent. 2014, 15, 6-7. [CrossRef]

13. Quintas, V.; Prada-López, I.; Carreira, M.J.; Suárez-Quintanilla, D.; Balsa-Castro, C.; Tomás, I. In situ antibacterial activity of essential oils with and without alcohol on oral biofilm: A randomized clinical trial. Front. Microbiol. 2017, 8, 2162. [CrossRef]

14. Vlachojannis, C.; Winsauer, H.; Chrubasik, S. Effectiveness and safety of a mouthwash containing essential oil ingredients. Phytother. Res. 2013, 27, 685-691. [CrossRef]

15. Sheen, S.; Addy, M. An in vitro evaluation of the availability of cetylpyridinium chloride and chlorhexidine in some commercially available mouthrinse products. Br. Dent. J. 2003, 194, 16-19. [CrossRef]

16. Mehdipour, M.; Taghavi Zenoz, A.; Asvadi Kermani, I.; Hosseinpour, A. A comparison between zinc sulfate and chlorhexidine gluconate mouthwashes in the prevention of chemotherapy-induced oral mucositis. DARU J. Pharm. Sci. 2011, 19, 71-73.

17. Najafi, M.H.; Taheri, M.; Mokhtari, M.R.; Forouzanfar, A.; Farazi, F.; Mirzaee, M.; Ebrahiminik, Z.; Mehrara, R. Comparative study of $0.2 \%$ and $0.12 \%$ digluconate chlorhexidine mouth rinses on the level of dental staining and gingival indices. Dent. Res. J. 2012, 9, 305-308.

18. Marsh, P.D. Controlling the oral biofilm with antimicrobials. J. Dent. 2010, 38, S11-S15. [CrossRef]

19. Davison, J.; Maillard, J. Opinion on Triclosan-Antimicrobial Resistance; European Union: Brussels, Belgium, 2010; ISBN 9789279124846.

20. Storehagen, S.; Ose, N.; Midha, S. Dentifrices and Mouthwashes Ingredients and Their Use. Master's Thesis, University of Oslo, Oslo, Norway, 2003.

21. Sreenivasan, P.; Gaffar, A. Antiplaque biocides and bacterial resistance: A review. J. Clin. Periodontol. 2002, 29, 965-974. [CrossRef]

22. Alencar, M.A.S.D.S.; Martinez, E.F.; Figueiredo, F.C.; De Lima e Silva, A.R.; Protazio, J.E.; Bertamoni, M.; Peruzzo, D.C.; Napimoga, M.H. The Evaluation of Osteoblastic Cell Behavior on Treated Titanium Surface. Open Dent. J. 2019, 14, 1-6. [CrossRef]

23. Halboub, E.; Al-Maweri, S.A.; Al-Wesabi, M.; Al-Kamel, A.; Shamala, A.; Al-Sharani, A.; Koppolu, P. Efficacy of propolis-based mouthwashes on dental plaque and gingival inflammation: A systematic review. BMC Oral Health 2020, 20, 198. [CrossRef]

24. Eslami, N.; Ahrari, F.; Rajabi, O.; Zamani, R. The staining effect of different mouthwashes containing nanoparticles on dental enamel. J. Clin. Exp. Dent. 2015, 7, e457-e461. [CrossRef] 
25. Azimi, M.; Jouybari, L.; Moghadam, S.; Ghaemi, E.; Behnampoor, N.; Sanagoo, A.; Hesam, M. Antimicrobial effects of chlorhexidine, matrica drop mouthwash (chamomile extract), and normal saline on hospitalized patients with endotracheal tubes. Iran. J. Nurs. Midwifery Res. 2016, 21, 458. [CrossRef]

26. Bahlouli, S.; Aghazadeh, Z.; Aghazadeh, M.; Shojani, S.; Kafil, H.S. Determining the Antibacterial Activity of Chlorhexidine Mouthwashes with and without Alcohol against Common Oral Pathogens. J. Adv. Oral Res. 2018, 9, 15-19. [CrossRef]

27. Vranić, E.; Lacević, A.; Mehmedagić, A.; Uzunović, A. Formulation ingredients for toothpastes and mouthwashes. Bosn. J. Basic Med. Sci. 2004, 4, 51-58. [CrossRef] [PubMed]

28. Keegan, G.M.; Smart, J.D.; Ingram, M.J.; Barnes, L.M.; Burnett, G.R.; Rees, G.D. Chitosan microparticles for the controlled delivery of fluoride. J. Dent. 2012, 40, 229-240. [CrossRef] [PubMed]

29. Subramaniam, P.; Nandan, N. Effect of xylitol, sodium fluoride and triclosan containing mouth rinse on Streptococcus mutans. Contemp. Clin. Dent. 2011, 2, 287-290. [CrossRef]

30. O'Mullane, D.M.; Baez, R.J.; Jones, S.; Lennon, M.A.; Petersen, P.E.; Rugg-Gunn, A.J.; Whelton, H.; Whitford, G.M. Fluoride and Oral Health. Community Dent. Health. 2016, 33, 69-99.

31. Liao, Y.; Brandt, B.W.; Li, J.; Crielaard, W.; Van Loveren, C.; Mei, D. Fluoride resistance in Streptococcus mutans: A mini review. J. Oral Microbiol. 2017, 9, 1344509. [CrossRef]

32. Pretty, I.A. High Fluoride Concentration Toothpastes for Children and Adolescents. Caries Res. 2016, 50, 9-14. [CrossRef]

33. Kavouklis, N.M.; Gaudreault, R.A. Oral Care Formulations with Hydrogen Peroxide and Lycopene. U.S. Patent 11/491,187, 24 July 2006.

34. Kasaai, M.R.; Arul, J.; Charlet, G. Fragmentation of Chitosan by Acids. Sci. World J. 2013, 2013, 508540. [CrossRef]

35. Sahariah, P.; Gaware, V.S.; Lieder, R.; Jónsdóttir, S.; Hjálmarsdóttir, M.; Sigurjonsson, O.E.; Másson, M. The effect of substituent, degree of acetylation and positioning of the cationic charge on the antibacterial activity of quaternary chitosan derivatives. Mar. Drugs 2014, 12, 4635-4658. [CrossRef]

36. Islam, S.; Bhuiyan, M.A.R.; Islam, M.N. Chitin and Chitosan: Structure, Properties and Applications in Biomedical Engineering. J. Polym. Environ. 2017, 25, 854-866. [CrossRef]

37. Rahayu, D.P.; De Mori, A.; Draheim, R.R.; Lalatsa, A.; Roldo, M. Enhancing the antibacterial effect of chitosan to combat orthopaedic implant-associated infections. Carbohydr. Polym. 2021. submitted.

38. Lalatsa, A.; Garrett, N.L.; Ferrarelli, T.; Moger, J.; Schätzlein, A.G.; Uchegbu, I.F. Delivery of peptides to the blood and brain after oral uptake of quaternary ammonium palmitoyl glycol chitosan nanoparticles. Mol. Pharm. 2012, 9, 1764-1774. [CrossRef]

39. Kubota, N.; Tatsumoto, N.; Sano, T.; Toya, K. A simple preparation of half N-acetylated chitosan highly soluble in water and aqueous organic solvents. Carbohydr. Res. 2000, 324, 268-274. [CrossRef]

40. Churchley, D.; Rees, G.D.; Barbu, E.; Nevell, T.G.; Tsibouklis, J. Fluoropolymers as low-surface-energy tooth coatings for oral care Int. J. Pharm. 2008, 352, 44-49. [CrossRef]

41. Medina-Flores, D.; Ulloa-Urizar, G.; Camere-Colarossi, R.; Caballero-García, S.; Mayta-Tovalino, F.; del Valle-Mendoza, J. Antibacterial activity of Bixa orellana L. (achiote) against Streptococcus mutans and Streptococcus sanguinis. Asian Pac. J. Trop. Biomed. 2016, 6, 400-403. [CrossRef]

42. Pasquantonio, G.; Greco, C.; Prenna, M.; Ripa, C.; Vitali, L.A.; Petrelli, D.; Di Luca, M.C.; Ripa, S. Antibacterial activity and anti-biofilm effect of chitosan against strains of Streptococcus mutans isolated in dental plaque. Int. J. Immunopathol. Pharmacol. 2008, 21, 993-997. [CrossRef]

43. Lemos, J.A.; Abranches, J.; Koo, H.; Marquis, R.E.; Burne, R.A. Protocols to study the physiology of oral biofilms. Methods Mol. Biol. 2010, 666, 87-102. [CrossRef]

44. Anshula, D.; Rameshwari, R.; Poonacha, K.; Seema, B.; Monika, K.; Neha, P. Evaluation of the Stability, pH, Density and Sedimentation of Green Tea and Green Tea Plus Ginger Mouthwash: A Phytochemical Study. J. Oral Heal. Dent. Sci. 2018, 2. [CrossRef]

45. Depan, D.; Pesacreta, T.C.; Misra, R.D.K. The synergistic effect of a hybrid graphene oxide-chitosan system and biomimetic mineralization on osteoblast functions. Biomater. Sci. 2014, 2, 264-274. [CrossRef]

46. Liu, M.; Xu, H.; Ma, Y.; Cheng, J.; Hua, Z.; Huang, G. Osteoblasts proliferation and differentiation stimulating activities of the main components of Epimedii folium. Pharmacogn. Mag. 2017, 13, 90-94. [CrossRef]

47. Okamoto, H.; Taguchi, H.; Iida, K.; Danjo, K. Development of polymer film dosage forms of lidocaine for buccal administration. J. Control. Release 2001, 77, 253-260. [CrossRef]

48. Panda, P.K.; Yang, J.M.; Chang, Y.H.; Su, W.W. Modification of different molecular weights of chitosan by p-Coumaric acid: Preparation, characterization and effect of molecular weight on its water solubility and antioxidant property. Int. J. Biol. Macromol. 2019, 136, 661-667. [CrossRef] [PubMed]

49. Mao, S.; Shuai, X.; Unger, F.; Simon, M.; Bi, D.; Kissel, T. The depolymerization of chitosan: Effect on physicochemical and biological properties. Int. J. Pharm. 2004, 281, 45-54. [CrossRef] [PubMed]

50. Lin, H.; Chen, L.; Yan, G.; Chen, F.; Huang, L. Preparation of Drug-loaded Chitosan Microspheres and Its Application in Paper-based PVC Wallpaper. IOP Conf. Ser. Mater. Sci. Eng. 2018, 322. [CrossRef]

51. Neel, E.A.A.; Aljabo, A.; Strange, A.; Ibrahim, S.; Coathup, M.; Young, A.M.; Bozec, L.; Mudera, V. Demineralizationremineralization dynamics in teeth and bone. Int. J. Nanomed. 2016, 11, 4743-4763. [CrossRef] 
52. Burak, A.K.; Özeroğlu, E.; Taspinar, M. The use of methylene blue as mouthwash in periodontology. East. J. Med. 2015, 20, 215-221.

53. Verma, U.P.; Gupta, A.; Yadav, R.K.; Tiwari, R.; Sharma, R.; Balapure, A.K. Cytotoxicity of chlorhexidine and neem extract on cultured human gingival fibroblasts through fluorescence-activated cell sorting analysis: An in-vitro study. Eur. J. Dent. 2018, 12, 344-349. [CrossRef]

54. Jain, G.; Khar, R.K.; Ahmad, F.J. Theory and Practice of Physical Pharmacy-E-Book; Elsevier: New Delhi, India, 2012; ISBN 978-81-312-2824-1.

55. Ojha, S. Formulation and Evaluation of Antibacterial Herbal Mouthwash Against Oral Disorders. Indo Glob. J. Pharm. Sci. 2018, 8, 37-40. [CrossRef]

56. Hyunh-Ba, K.; Zahn, M. Understanding ICH Guidelines Applicable to Stability Testing. In Handbook of Stability Testing in Pharmaceutical Development: Regulations, Methodologies, and Best Practices; Hyunh-Ba, K., Ed.; Springer: New York, NY, USA, 2008.

57. Pini, N.I.P.; Lima, D.A.N.L.; Luka, B.; Ganss, C.; Schlueter, N. Viscosity of chitosan impacts the efficacy of F/Sn containing toothpastes against erosive/abrasive wear in enamel. J. Dent. 2020, 92, 103247. [CrossRef]

58. Costa, E.M.; Silva, S.; Pina, C.; Tavaria, F.K.; Pintado, M.M. Evaluation and insights into chitosan antimicrobial activity against anaerobic oral pathogens. Anaerobe 2012, 18, 305-309. [CrossRef]

59. Sahariah, P.; Cibor, D.; Zielińska, D.; Hjálmarsdóttir, M.; Stawski, D.; Másson, M. The effect of molecular weight on the antibacterial activity of N,N,N-trimethyl chitosan (TMC). Int. J. Mol. Sci. 2019, 20, 1743. [CrossRef]

60. Chow, L.C.; Takagi, S.; Frukhtbeyn, S.; Sieck, B.A.; Parry, E.E.; Liao, N.S.; Schumacher, G.E.; Markovic, M. Remineralization Effect of a Low-Concentration Fluoride Rinse in an Intraoral Model. Caries Res. 2002, 36, 136-141. [CrossRef] 